\title{
Can the Nasal Schirmer Test be Used as a Topographic Test in Facial Paralysis Patients?
}

\section{Nazal Schirmer Testi Fasiyal Paralizi Hastalarında Topografik Bir Test Olarak Kullanılabilir mi?}

\author{
(D) Muhammet YILDIZ1, (D) Ahmet BAKI²
}

1Antalya Training and Research Hospital, Clinic of Otolaryngology, Antalya, Turkey

2Üsküdar State Hospital, Clinic of Otolaryngology, İstanbul, Turkey

\begin{abstract}
Objective: Mucociliary clearance is an important defense mechanism of the respiratory system. One of the main factors determining mucociliary clearance is the ciliary activity of the respiratory epithelium. The amount of nasal secretion can be easily determined by the recently used nasal Schirmer test. The aim of this study was to investigate the amount of nasal secretion in patients with facial paralysis.
\end{abstract}

Methods: A total of 50 patients with unilateral facial paralysis were included in the study. Eye and nasal Schirmer test were applied to the patients. The eye Schirmer test results were calculated after 5 minutes and the nasal Schirmer test results were calculated after 10 minutes, in millimeters according to the amount of wetting of the test papers. Schirmer test results of paralyzed and nonparalyzed sides were compared with each other.

Results: The mean paralytic and non-paralytic side eye Schirmer test values of the patients with facial paralysis were $11.14 \pm 4.80$ and $19.54 \pm 4.01$, respectively. Mean paralytic and non-paralytic side nasal Schirmer test values were $10.92 \pm 4.82$ and $20.54 \pm 4.31$, respectively. Eye and nasal Schirmer test values of the paralytic side were significantly lower than the non-paralytic side $(\mathrm{p}<0.05)$. In the right facial paralysis group; the right eye and nasal Schirmer test results were significantly lower than the left side results $(p<0.05)$. In the left facial paralysis group; the left eye and nasal Schirmer test were significantly lower than the right side results $(\mathrm{p}<0.05)$. Nasal

\section{ÖZ}

Amaç: Mukosiliyer klirens solunum sisteminin önemli bir defans mekanizmasıdır. Mukosiliyer klirensi belirleyen ana faktörlerden biri solunum epitelinin siliyer aktivitesidir. Nazal sekresyon miktarı son zamanlarda sık kullanılan nazal Schirmer testi ile kolaylıkla belirlenebilmektedir. Bu çalışmanın amacı fasiyal paralizisi olan hastalarda nazal sekresyon miktarını araştırmaktır.

Yöntemler: Çalışmaya tek taraflı fasiyal paralizisi olan toplam 50 hasta dahil edildi. Hastaların paralizisi olan ve olmayan taraflarına öncelikle göz Schirmer ve daha sonra nazal Schirmer testleri uygulandı. Göz Schirmer test sonuçları 5 dakika sonra ve nazal Schirmer test sonuçları 10 dakika sonra test kağıtlarının ıslanma miktarına göre milimetre cinsinden hesaplandı. Paralizi olan ve olmayan tarafların test sonuçları birbirleriyle karşılaştırıldı.

Bulgular: Fasiyal paralizi hastalarının paralitik ve paralitik olmayan taraf göz Schirmer değerleri ortalaması sırasıyla $11,14 \pm 4,80$ ve $19,54 \pm 4,01$ olarak saptand. Paralitik ve paralitik olmayan taraf nazal Schirmer değerleri ortalaması sırasıyla $10,92 \pm 4,82$ ve $20,54 \pm 4,31$ olarak saptand. Paralitik taraf göz ve nazal Schirmer değerleri paralitik olmayan tarafa göre istatistiksel olarak anlamlı düzeyde düşük bulundu $(\mathrm{p}<0,05)$. Sağ fasiyal paralizi grubunda, sağ taraf göz ve nazal Schirmer değerleri sol tarafa göre istatiksel anlamlı düşük saptandı $(\mathrm{p}<0,05)$. Sol fasiyal paralizi grubunda, sol taraf göz ve nazal Schirmer değerleri sağ tarafa göre istatiksel anlamlı düşük saptandı $(\mathrm{p}<0,05)$. Grade 2-3 ile Grade 4-5 fasiyal paraliziye sahip

Address for Correspondence: Ahmet BAKi, Üsküdar State Hospital, Clinic of Otolaryngology, İstanbul, Turkey

E-mail: dr.ahmet170@gmail.com ORCID ID: orcid.org/0000-0003-2851-0849 
Schirmer test results of Grade 2-3 and Grade 4-5 facial paralysis patients were not statistically significant $(\mathrm{p}>0.05)$.

Conclusion: In this study, the amount of nasal secretion on the paralysis side of the patients with unilateral facial paralysis was lower than the contralateral side. Further studies are needed to determine whether decreased secretion improves in long-term follow-up and the prognostic significance of nasal dryness in facial paralysis.

Keywords: Facial paralysis, intranasal Schirmer test, nasal secretion hastaların nazal Schirmer test sonuçlarında istatiksel anlamlı farklılık saptanmadi $(p>0,05)$.

Sonuç: Bu çalışmada tek taraflı fasiyal paralizisi olan hastaların paralizi tarafında karşı tarafa göre daha düşük nazal sekresyon miktarı tespit edildi. Daha geniş hasta serilerinde azalmış sekresyonun düzelip düzelmediğini ve nazal kuruluğun fasiyal paralizide prognostik önemini ortaya koyacak yeni çalışmalara ihtiyaç vardır.

Anahtar Sözcükler: Fasiyal paralizi, nazal Schirmer test, nazal sekresyon

\section{Introduction}

Mucociliary clearance is an important protection mechanism of the upper and lower respiratory tract. The removal of foreign particles and pathogens from the inhaled air is achieved by the mucociliary function maintained by the collective work of the cilia, mucus cover, and mucus-producing glands (1). Nasal secretion protects the airway epithelium from the harmful effects of the external environment and contributes to the maintenance of normal physiology by keeping the mucosa moist (2,3). Many environmental and individual factors affected the amount of nasal secretion $(4,5)$.

Nasal mucosal secretion and its contents are controlled by the autonomic nervous system. In addition, the parasympathetic activity increases both the amount of secretion and nasal congestion. Any reduction in the parasympathetic activity leads to a more viscous secretion that may alter the mucociliary clearance rate of the nasal mucosa. The parasympathetic innervation of the nasal mucosa is controlled by the superior salivatory nucleus located in the pons. The parasympathetic fibers then continue in the nervus intermedius and coexist with the internal acoustic canal and fallopian canal with the facial nerve $(6,7)$.

Bell's paralysis, also called idiopathic facial paralysis, is the most common form of facial paralysis. The annual incidence varies between 15 and 40 per 100,000. It is most commonly seen in 15-45 age groups, without difference in terms of gender and race. Typically, it is a peripheral sub-motor neuron paralysis that is self-limiting, with acute-onset and of unknown cause, affecting all muscle groups on only one side of the face (8-10). Any condition that affects facial nerve function may also affect the nervus intermedius. The greater petrosal nerve, a branch of $\mathrm{N}$. intermedius, provides parasympathetic innervation of the lacrimal glands, and the Schirmer test is used as a topographic test to demonstrate a reduction in the amount of tears in Bell's palsy (11). The greater petrosal nerve also carries parasympathetic fibers to the nasal cavity and plays a significant role in the amount of nasal secretion and mucociliary clearance. The nasal Schirmer test is an inexpensive, simple, effective, and non-adverse method used to objectively determine the amount of nasal secretion. The amount of nasal secretion was first shown by Saunte, and the effects of a parasympathetic drug (pilocarpine) on tears, saliva, and nasal secretions were determined (12).

No article investigating the effect of Bell's paralysis on nasal mucosal secretion has been reported. Thus, this study aimed to investigate the changes in the amount of nasal secretion between the paralyzed side and normal facial functions in patients with unilateral Bell's paralysis using the nasal Schirmer test.

\section{Method}

This study was planned as a prospective study by the otorhinolaryngology clinic and started after the approval of the ethics committee. Participants were informed about the study, and informed consent was obtained. The study was carried out in accordance to the principles of the Helsinki Declaration. A total of 67 patients with peripheral facial paralysis underwent detailed otorhinolaryngologic examination and nasal endoscopic examination. Inclusion criteria for patients with Bell palsy include the following: presence of unilateral facial palsy for $<2$ weeks without previously medical treatment for facial palsy, no known nasal-paranasal sinus symptoms or nasal-paranasal sinus surgery, and normal nasal examination findings. Exclusion criteria for Bell palsy patients includes the following: patients with facial palsy duration of $>2$ weeks, previous medical treatment for Bell palsy disease, nasal and paranasal disease symptoms such as allergic rhinitis and rhinosinusitis, nasal septal deviation, nasal polyps, nasal mucosal abnormalities and other structural nasal abnormalities, diabetes mellitus, hepatic impairment, chronic renal failure, hypo or hyper thyroidism, history of topical or systemic drug use affecting the nasal physiology (topical or oral decongestant, antihypertensive, antidepressant, antipsychotic, etc.), smoking and alcohol consumption. In addition, patients with recent head trauma, psychiatric disorder, autoimmune disease, neurodegenerative disease, previous radiotherapy to the head and neck region, and with signs and symptoms of upper respiratory tract infection on the day of the test were also excluded. Steroids and other treatments were started after the eye and nasal Schirmer tests. Facial nerve function was evaluated according to the House Brackmann staging system. A total of 17 patients were excluded from the study. Therefore, 50 patients with facial palsy participated in the study. Patients were divided into two groups as 23 right and 27 left peripheral facial paralysis groups. Age, gender, facial paralysis degree, and admission days of patients were recorded.

\section{Eye and Nasal Schirmer Test}

After the patients were adapted to the hospital environment for 15-30 $\mathrm{min}$, they were taken to the Schirmer test room. Environmental temperature was recorded as $20.25^{\circ} \mathrm{C} \pm 0.87^{\circ} \mathrm{C}$ 
$\left(18.3{ }^{\circ} \mathrm{C}-21.9^{\circ} \mathrm{C}\right)$ and humidity as $45.34 \pm 14.26(23 \%-68 \%)$. For eye and nasal Schirmer test, standard Schirmer test paper of $35 \mathrm{~mm}$ length and $5 \mathrm{~mm}$ width was used (ERC SCHIRMER Tear Test Strip, Turkey). This paper was first curled about 5 $\mathrm{mm}$ at one end and inserted into the lower fornix between the middle third and the outer third of the two eyes. Care was taken not to touch the cornea. The test was performed in a dimly lit environment, and the patient was asked not to look at any light source to avoid reflex stimulation. The amount of wetting on the paper was recorded in millimeters $(\mathrm{mm})$ after waiting for 5 minutes. The nasal Schirmer test paper was folded at an angle of 45 degrees from an area of approximately $5 \mathrm{~mm}$ from one end, and then placed bilaterally with the help of a speculum and bayonet in parallel with the nasal dorsum and anterior nasal septum after an anterior rhinoscopic examination. The $5 \mathrm{~mm}$ portion of the test paper was placed in contact with the anterior nasal mucosa and the rest of the test paper overflowing from the nostril. During this period, care was taken not to touch the turbinates on the lateral nasal wall. After waiting for 10 minutes, the amount of wetting of the paper was recorded in $\mathrm{mm}$.

\section{Statistical Analysis}

Statistical Package for the Social Sciences 22 program was used for statistical analysis. The suitability of parameters to normal distribution was evaluated by Shapiro-Wilks test. Descriptive statistical methods (mean and standard deviation) were determined when evaluating the study data. Wilcoxon Signed Rank test was used to evaluate the dependent non-parametric data. One-way Analysis of variance test was used to compare the groups in terms of stages. $\mathrm{P}<0.05$ was considered statistically significant.

\section{Results}

Ages of patients ranged from 18 to 79 years, and the mean age of patients was $42.88 \pm 14.93$ years. $60 \%$ of patients were female and $40 \%$ were male. A total of 23 patients had right facial paralysis and 27 patients had left side facial paralysis. On the first day, $78 \%$ of patients applied, whereas $10 \%$ on the second day, $6 \%$ on the third day, $4 \%$ on the fifth day, and $2 \%$ on the seventh day. It was found that $46 \%$ of patients presented at the $2^{\text {nd }}$ stage, $38 \%$ at the $3^{\text {rd }}$ stage, $8 \%$ at the $4^{\text {th }}$ stage, and $8 \%$ at the $5^{\text {th }}$ stage (Table 1 ).

The paralytic eye Schirmer values of patients with facial paralysis ranged from 5 to 26 and the mean value was $11.14 \pm 4.80$. The eye Schirmer values of the non-paralytic side ranged between 14 and 30 and the mean value was $19.54 \pm 4.01$. Paralytic side nasal Schirmer values ranged from 4 to 23 and the mean value was $10.92 \pm 4.82$. The nasal Schirmer values of the non-paralytic side ranged between 13 and 34 and the mean value was $20.54 \pm 4.31$. The eye Schirmer values on the paralytic side were significantly lower than the non-paralytic side $(\mathrm{p}=0.001)$ (Table 2). Nasal Schirmer values on the paralytic side were significantly lower than the non-paralytic side $(\mathrm{p}=0.001)$ (Table 2).

The right eye Schirmer values of 23 patients with right facial paralysis ranged from 8 to 26 , with a mean value of $13.13 \pm 6.01$. Schirmer values of the left eye ranged from 15 to 30 , with a mean value of $20.82 \pm 4.98$. Right nasal Schirmer values ranged from 5 to 22 , with a mean value of $11.30 \pm 5.14$. Left nasal Schirmer values ranged from 15 to 34 , with a mean value of $21.00 \pm 4.35$. In the right facial paralysis group, Schirmer results of the right eye were significantly lower than that of the left eye $(\mathrm{p}=0.001)$ (Table 3). The right nasal Schirmer results were found to be significantly lower than that of the left nasal cavity $(\mathrm{p}=0.001)$ (Table 3).

The left eye Schirmer values of 27 patients with left facial paralysis ranged from 5 to 14 , with a mean value of $9.44 \pm 2.53$. Schirmer values of the right eye ranged from 14 to 25 , with a mean value of $18.44 \pm 2.56$. Left nasal Schirmer values ranged from 4 to 23 , with a mean value of $10.59 \pm 4$.60. The right nasal Schirmer values ranged between 13 and 32, with a mean

Table 1. Demographic data of patients with facial paralysis

\begin{tabular}{l|l}
\hline Male/female (number patients) & $20 / 30$ \\
\hline $\begin{array}{l}\text { Age (years)/mean } \pm \text { SD } \\
\text { Facial paralysis side (\%) }\end{array}$ & $42.88 \pm 14$. \\
\hline Right & $23(46 \%)$ \\
Left & $27(54 \%)$ \\
\hline Stage (House-Brackmann) (\%) & \\
\hline Stage 2 & $23(46 \%)$ \\
\hline Stage 3 & $19(38 \%)$ \\
\hline $\begin{array}{l}\text { Stage } 4 \\
\text { Stage } 5\end{array}$ & $4(8 \%)$ \\
\hline $\begin{array}{l}\text { Applied day (number-\%) } \\
1^{\text {st }} \text { day }\end{array}$ & $4(8 \%)$ \\
\hline $2^{\text {nd }}$ day & $39(78 \%)$ \\
\hline $3^{\text {th }}$ day & $5(10 \%)$ \\
\hline $5^{\text {th }}$ day & $3(6 \%)$ \\
\hline $7^{\text {th }}$ day & $2(4 \%)$ \\
\hline SD & $1(2 \%)$ \\
\hline
\end{tabular}

SD: Standard deviation

Table 2. Comparison of eye and nasal Schirmer test values of sides with and without facial paralysis

\begin{tabular}{|c|c|c|c|}
\hline Schirmer test & $\begin{array}{l}\text { Paralytic side } \\
\text { mean } \pm \text { SD (min-max) } \\
(\mathrm{mm})\end{array}$ & $\begin{array}{l}\text { Non-paralytic side } \\
\text { mean } \pm \text { SD (min-max) } \\
(\mathrm{mm})\end{array}$ & $p$ \\
\hline Eye $(n=50)$ & $11.14 \pm 4.80(5-26)$ & $19.54 \pm 4.01(14-30)$ & 0.001 \\
\hline Nose $(n=50)$ & $10.92 \pm 4.82(4-23)$ & $20.54 \pm 4.31(13-34)$ & 0.001 \\
\hline
\end{tabular}


value of 20.14 4 4.32. In the left facial paralysis group, the left eye Schirmer results were found to be statistically lower than that of the right eye $(\mathrm{p}=0.001)$ (Table 3). Left nasal Schirmer results were significantly lower than that of the right nasal cavity $(\mathrm{p}=0.001)$ (Table 3).

According to House Brackmann staging, no statistically significant difference were found in nasal Schirmer test results of patients with Grade 2-3 and Grade 4-5 facial paralysis ( $p>0.05$ ) (Table 4).

\section{Discussion}

In this study, patients with unilateral facial paralysis were evaluated objectively using the eye and nasal Schirmer tests, and lower Schirmer test results were obtained on the paralyzed side than the non-paralyzed side.

The fact that the nasal mucosa is rich in vascular and glandular structures plays an important role both for mucus layer and mucociliary movement. Any factor affecting the mucus layer also has an effect on mucociliary clearance. Nasal glandular secretion is important for nasal mucociliary clearance (13).

Functional problems seen in the lacrimal gland in facial paralysis patients may also be seen in the nasal glands. Changes in the amount and content of nasal secretion affect mucociliary clearance (14). Based on this idea, we planned to investigate the changes in the amount of nasal secretion in patients with unilateral Bell's paralysis with the nasal Schirmer test.

Schirmer test is frequently used in cases where lacrimal function provides information and decreases the amount of tears for various reasons (15). Modified intraoral Schirmer test is used to determine the amount of saliva in cases of salivary gland hypofunction (16). The nasal Schirmer test is an inexpensive and easy to use method that has recently been used and does not cause discomfort to determine the amount of nasal secretion. Server et al. (17) showed that intranasal Schirmer test is a simple and practical method that can be used to determine the amount of nasal secretion in the Turkish population. In addition, the mean value of normal values for the Turkish population was $19 \pm 7 \mathrm{~mm}$, and no statistically significant difference was found between test results in terms of gender. In our study, we obtained the Schirmer test results similar to this study in nasal cavities without facial paralysis.

Lindemann et al. (18) performed a nasal Schirmer test for the quantitative assessment of the amount of nasal secretion on 159 non-smokers and 30 smokers. The nasal Schirmer test results of the volunteers who smoked were significantly lower than the control group. In our study, patients who are smoking were excluded from the study to avoid confusing factors.

Boynuegri et al. (19) examined the nasal mucociliary clearance times of patients that are paralyzed and non-paralyzed in 38 patients diagnosed with Bell palsy rhinoscintigraphically. They found a statistically significant increase in clearance time on the paralyzed side compared to the opposite side. The increase of the clearance time is due to reduced parasympathetic activity in the nasal cavity on the paralysis side. This situation was explained by mucosal dryness resulting from decreased mucus secretion as a result of decreased parasympathetic activity. Thus, our study aimed to evaluate the amount of nasal secretion in patients with unilateral facial paralysis using the nasal Schirmer test. Nasal Schirmer test showed a statistically significant decrease in the amount of nasal secretion on the side with facial paralysis compared to the side without paralysis.

\section{Table 3. Comparison of nasal and eye Schirmer test values according to facial paralysis side}

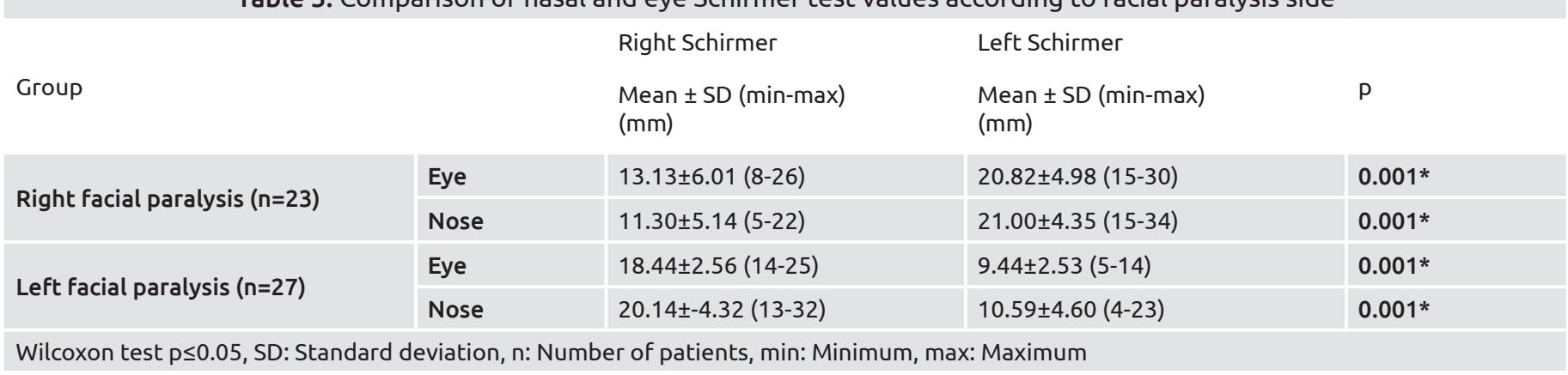

Table 4. Comparison of nasal Schirmer test values of patients according to Hause-Brackmann stage

\begin{tabular}{|l|l|l|l|}
\hline House-Brackmann stage & $\begin{array}{l}\text { Paralytic side nasal Schirmer } \\
\text { mean } \pm \text { SD (min-max) } \\
(\mathrm{mm})\end{array}$ & $\mathrm{P}$ & $\begin{array}{l}\text { Non-paralytic side nasal Schirmer } \\
\text { mean } \pm \text { SD (min-max) } \\
(\mathrm{mm})\end{array}$ \\
\hline Grade $2-3(n=42)$ & $\begin{array}{l}11.42 \pm 5.04 \\
(4-23)\end{array}$ & 0.766 & $\begin{array}{l}21.11 \pm 4.29 \\
(15-34)\end{array}$ \\
\hline Grade $4-5(n=8)$ & $8.25 \pm 2.05$ & $17.50 \pm 3.16$ \\
\hline
\end{tabular}

One-way analysis of variance test $p \leq 0.05, S D$ : Standard deviation, n: Number of patients, min: Minimum, max: Maximum 
The cornea needs to be protected in facial paralysis as a result of weakness in eye closure and a decrease in tear amount (20). Tear drops and eye ointments are often used for this purpose. Sterile eye closure or the use of eye protection glasses is recommended to eliminate these possible risks in the cornea (21). In our study, dryness of the eye Schirmer values on the side that developed facial paralysis was found to be statistically significant compared to the other side, thus, preventive treatments and precautions were recommended to these patients. Due to facial paralysis, the sphincter function of the orbicularis oris muscle is impaired as a result of this condition oral incontinence impaired, thus abrasion and ulceration of the lip and cheek mucosa can be observed. These complications can be prevented by developing strategic eating habits (using pipettes for liquids, turning to a soft diet, etc.) and using dental spacers to prevent buccal mucosal irritation during chewing (22). In this study, a decrease in the amount of nasal secretion in the nasal cavity on the side with facial paralysis was found. In addition, impairment of the mucociliary clearance due to facial paralysis has been shown in the literature. The use of nasal moisturizers to promote a nasal mucociliary activity or the development of other treatment modalities may help in preventing nasal or paranasal complications. New clinical studies are needed to detect and manage various nasal and paranasal complications that may develop due to facial paralysis.

\section{Study Limitations}

Limitations of this study were the low number of patients and the inability to investigate whether the decreased nasal Schirmer values changed after the treatment. In addition, the fact that the prognostic value of decreased nasal Schirmer values on the paralyzed side during the follow-up of patients was not investigated is another limitation.

\section{Conclusion}

In unilateral facial paralysis, a statistically significant decrease was found in the nasal Schirmer test results on the side with paralysis compared to the side without paralysis. Further studies are needed to investigate the effects of reduced nasal secretion caused by unilateral facial paralysis on the nasal mucosa and paranasal sinuses.

\section{Ethics}

Ethics Committee Approval: Approval for the study was granted by the Zeynep Kamil Women and Children Diseases Training and Research Hospital Ethics Committee (Protocol Number: 89).

Informed Consent: Written informed consent was obtained from the patients.

Peer-review: Externally peer reviewed.

\section{Authorship Contributions}

Surgical and Medical Practices: A.B., Concept: A.B., M.Y., Design: A.B., M.Y., Data Collection or Processing: A.B., Analysis or Interpretation: A.B., M.Y., Literature Search: A.B., M.Y., Writing: A.B., M.Y.
Conflict of Interest: No conflict of interest was declared by the authors.

Financial Disclosure: The authors declared that this study received no financial support.

\section{References}

1. Soylu Özler G, Akbay E, Akkoca AN, Karapınar OS, Şimşek GÖ. Does menopause effect nasal mucociliary clearance time? Eur Arch Otorhinolaryngol 2015;272:363-6.

2. Keck T, Rozsasi A, Gruen PM. Konditionierung der Atemluft in der Nase [Nasal-air conditioning]. HNO 2011;59:40-4.

3. Kastl KG, Rettinger G, Keck T. The impact of nasal surgery on airconditioning of the nasal airways. Rhinology 2009;47:237-41.

4. Lindemann J, Sannwald D, Wiesmiller K. Age-related changes in intranasal air conditioning in the elderly. Laryngoscope 2008;118:1472-5.

5. Noback ML, Harvati K, Spoor F. Climate-related variation of the human nasal cavity. Am J Phys Anthropol 2011;145:599-614.

6. Bleier BS, Schlosser RJ. Endoscopic anatomy of the postganglionic pterygopalatine innervation of the posterolateral nasal mucosa. Int Forum Allergy Rhinol 2011;1:113-7.

7. Baraniuk JN, Merck SJ. Neuroregulation of human nasal mucosa. Ann N Y Acad Sci 2009;1170:604-9.

8. Yeo SW, Lee DH, Jun BC, Chang KH, Park YS. Analysis of prognostic factors in Bell's palsy and Ramsay Hunt syndrome. Auris Nasus Larynx 2007;34:159-64.

9. Peitersen E. Bell's palsy: the spontaneous course of 2,500 peripheral facial nerve palsies of different etiologies. Acta Otolaryngol Suppl 2002;4-30.

10. Gilden DH. Clinical practice. Bell's Palsy. N Engl J Med 2004;351:1323-31.

11. Metwali H, Kniese K, Kardavani B, Gerganov V, Samii M. Nervus intermedius dysfunctions after vestibular schwannoma surgery: a prospective clinical study. J Neurosurg 2018;131:555-560.

12. Saunte C. Quantification of salivation, nasal secretion and tearing in man. Cephalalgia 1983;3:159-73.

13. Oozawa H, Kimura H, Noda T, Hamada K, Morimoto T, Majima Y. Effect of prehydration on nasal mucociliary clearance in low relative humidity. Auris Nasus Larynx 2012;39:48-52.

14. Jones $\mathrm{N}$. The nose and paranasal sinuses physiology and anatomy. Adv Drug Deliv Rev 2001;51:5-19.

15. Miller D, Greiner J. Corneal measurements and tests. In: Albert and Jakobiec's, ed. Principles and practice of ophthalmology. Saunders; 1994.p.4-13.

16. López-Jornet P, Camacho-Alonso F, Bermejo-Fenoll A. A simple test for salivary gland hypofunction using Oral Schirmer's test. J Oral Pathol Med 2006;35:244-8.

17. Server EA, Celebi OO, Longur ES, Yigit O. Applicability Of Nasal Schirmer Test On Turkish Population And Identifying Its Normal Range Values. İstanbul Med J 2018;19: 231-4. 
18. Lindemann J, Tsakiropoulou E, Rettinger G, Gutter C, Scheithauer MO, Picavet V, et al. The intranasal Schirmer test: a preliminary study to quantify nasal secretion. Eur Arch Otorhinolaryngol 2014;271:2963-7.

19. Boynuegri S, Ozer S, Peksoy I, Acikalin A, Tuna EÜ, Dursun E, et al. Rhinoscintigraphic analysis of nasal mucociliary function in patients with Bell's palsy. Niger J Clin Pract 2016;19:359-63.
20. Sohrab M, Abugo U, Grant M, Merbs S. Management of the eye in facial paralysis. Facial Plast Surg 2015;31:140-4.

21. Holland NJ, Weiner GM. Recent developments in Bell's palsy. BMJ 2004;329:553-7.

22. Eviston TJ, Croxson GR, Kennedy PG, Hadlock T, Krishnan AV. Bell's palsy: aetiology, clinical features and multidisciplinary care. J Neurol Neurosurg Psychiatry 2015;86:1356-61. 